\title{
Teacher's Perspective on Integration of Traditional Games as Media Science Learning in Junior High School
}

\author{
Dwi Lestari Handayani ${ }^{1, *}$ Jumadi $^{2}$ \\ ${ }^{I}$ Master of Natural Science Education, Faculty of Mathematics and Natural Sciences, Universitas Negeri \\ Yogyakarta, Indonesia \\ ${ }^{2}$ Department of Natural Science Education, Faculty of Mathematics and Natural Sciences, Universitas Negeri \\ Yogyakarta, Indonesia \\ "Corresponding author. Email: dwilestari.2019@student.uny.ac.id
}

\begin{abstract}
The study aims to determine science teachers' perspective on traditional games, on the integration of traditional games as media science learning, and relevant traditional games as media in science learning. This study is descriptive qualitative research. The population is 12 public and private junior high school science teachers of Purbalingga, Banjarnegara, Banyumas, and Kebumen districts. The data collected through literature review, questionnaires, and interviews. The analysis used the qualitative data analysis technique of Milles and Huberman's which consists of data reduction, display data, and concluding. It will be concluded that the majority of science teachers define traditional games as a folk game played by local children from ancient times, mostly in groups. The teachers have a positive view on the integration of traditional games in science learning to introducing and preserving traditional games while learning so provide a direct learning experience and make it easier for children to accept. Traditional games that will be integrated as media in science learning are seen from material elements and tools or materials used so that have a relationship between characteristics and content in science learning.
\end{abstract}

Keywords: Teachers perspective, Traditional games, Integration, Media science learning

\section{INTRODUCTION}

Indonesia culture was very complex which many forms of traditional culture, for example, traditional games. Over fifty games were played by people around the region of Indonesia [1]. This wealth is created possible because each region has its characteristics and kinds of play, although some have similarities [2]. Traditional games are the results of past cultural processes that are still thick with local wisdom values, which have an academic role in the learning process of a person, especially children [3]. Traditional games are carried out voluntarily and cause pleasure for the perpetrators and are regulated by game rules which are run based on traditions passed down from generation to generation [4]. Traditional games as a method of gaining movement experience that is useful for children's physical growth and development [5]. Traditional games are symbols of data from generation to generation and have various functions or messages behind them, which grow and develop in midst of society consistent with needs and natural conditions around them [6]. That is, traditional games are cultural identity as a tool to stimulate simpler learning and involve a learning environment [1].

The development of science and technology are a few things that can't be avoided, both positive and negative impacts. Now, the traditional games are forgotten by children since digital games are easily obtained through gadgets [7]. Interesting modern games sooner or later changes the position of traditional games as original in each society and culture of Indonesia [1]. Moreover, these games were seized from an earlier generation and passed on to the young generation through oral, sound, or presentations [8]. The types of games that are presented online or on gadgets make it increasingly 
rare for kids to play traditional games. Some traditional games have even disappeared due to not knowing the name, type, or way of playing.

Reintroducing to the younger generation very relevant to keep up the existence of traditional games. Traditional games influence on mental and physical of kids and contain moral messages and academic values [9]. Traditional games not only train intellectually, but also educate emotionally and spiritually, instill tolerance, cooperation, and courage in life. The formal education pathway is one of the strategic media to socialize. Education is largely not just a transfer of information, but as an activity of socialization and production of values, also as a process of shaping and building the character of students as the next generation [10]. The use of traditional games as media in learning must be done, especially in related subjects.

Natural Science is one of the disciplines that deals with searching for nature in a systematic or methodology [9]. It's necessary to strive for balance/harmony between knowledge and cultivation of scientific attitudes, additionally as local wisdom values that exist and develops in society [11]. The existence of traditional games that exist needs serious attention in developing science education in schools because it's buried in original science which will be useful for the lives of students themselves and society. The mixing of assorted concepts in science subjects is to use a transdisciplinarity approach, where the concepts of scientific disciplines (physics, chemistry, and biology) blend and are associated with problems encountered around them so learning becomes contextual [12]. Contextual teaching is learning that relates the material to contexts of reality, daily or directly associated with the environment [13]-[16].

Integration of traditional games as media science learning is hoped that the teacher won't only introduce traditional games and science content contained therein, but improve the abilities of students. Previous research studies [9], [17]-[19] had been found that the use of traditional games (Sasak, bentengan, and congklak) as media in learning not only introduced forms of traditional games but also increased the abilities of students (local cultural preservation, concepts understanding, learning outcomes, and learning motivation). The applying of integrated science learning with traditional games as media of learning, teacher's perspective on traditional games is incredibly important. Through this study, the focus of the research is: 1) what's the science teacher's perspective on traditional games; 2) what's the science teacher's perspective on the integration of traditional games as media in science learning; 3) what traditional games are relevant as media in science learning.

\section{RESEARCH METHODS}

The study uses descriptive qualitative research which can later be used as additional information or basis in determining science learning media integrated with traditional games to enhance certain abilities of students. The study population was 12 public and private junior high school science teachers in Purbalingga, Banjarnegara, Banyumas, and Kebumen districts. The data collected included: 1) the teacher's perspective about traditional games, 2) the teacher's perspective on the integration of traditional games as media science learning, and 3) relevant traditional games as media in science learning. Data collected through literature review, questionnaires, and interviews. Questionnaires and interviews were conducted to find out the opinions of several teachers regarding the integration of traditional games as media science learning. Meanwhile, the literature review is carried out to add information and strengthen the opinions or views of science teachers. Data analysis was applied by using Milles and Huberman's qualitative data analysis technique which consisted of three stages, namely: data reduction, display data, and concluding.

\section{RESULTS AND DISSCUSION}

This study succeeded in collecting data on teacher opinions regarding definitions, kinds of traditional games, the importance of integrating traditional games as media science learning, and relevant traditional games as media in science learning. The results of descriptive analysis of data questionnaire and interview with science teachers can be seen in the table. 
Table 1. Analysis of science teachers' understanding of traditional games

\begin{tabular}{|c|c|c|}
\hline No & Aspects viewed & Results \\
\hline 1 & Definition of traditional games & $\begin{array}{l}\text { Of the } 12 \text { respondents both from rural and urban areas, } \\
100 \% \text { know the definition of traditional games }\end{array}$ \\
\hline 2 & $\begin{array}{l}\text { The origin or source of traditional } \\
\text { games }\end{array}$ & $\begin{array}{l}3 \text { out of } 12 \text { respondents (25\%) know the origin or source of } \\
\text { traditional games and } 75 \% \text { of respondents don't know }\end{array}$ \\
\hline 3 & $\begin{array}{l}\text { Application of traditional games as } \\
\text { media science learning }\end{array}$ & $\begin{array}{l}5 \text { respondents }(42 \%) \text { strongly agree, } 6 \text { respondents }(50 \%) \\
\text { agree, and } 1 \text { respondent (8\%) disagree with the integration of } \\
\text { traditional games in science learning }\end{array}$ \\
\hline 4 & $\begin{array}{l}\text { The importance of implementing } \\
\text { traditional games as media in } \\
\text { science learning }\end{array}$ & $\begin{array}{l}8 \% \text { (1 respondent) stated that it was quite important, } 17 \% \text { (2 } \\
\text { respondents) stated that it was very important, and } 75 \%(9 \\
\text { respondents) stated that it's important to integrate traditional } \\
\text { games as media in } \\
\text { science learning }\end{array}$ \\
\hline
\end{tabular}

In Table 1, it can be seen that all respondents know the definition of traditional games but don't know their origin or source. This is because more than fifty games were played by people around the region of Indonesia [1]. This wealth is created possible because each region has its characteristics and forms of play, although some have similarities [2]. Therefore, the integration of traditional games in science learning needs to be applied. The hope is that it'll not only introduce traditional games and science content contained therein but also improve the abilities of students.

Traditional games as part of local wisdom have their characteristics. Likewise, with name or type, traditional games have their characteristics.
Therefore, the teacher's view of traditional games is important in process of using them as media in science learning. Based on the opinion of science teachers as seen in Table 2, the results show that majority of teachers haven't much different view of traditional games, namely folk games that are played for generation by local children from ancient times where most of them were done in groups. Sahidun [6] argued that traditional games are symbols of data from generation to generation and have various functions or messages behind them, which grow and develop within the midst of society per needs and conditions of surrounding nature. Traditional games are also carried out voluntarily and cause pleasure for the perpetrators and are governed by game rules which are run based on heredity traditions [4].

Table 2. Teachers' views of traditional games and their information as media in science learning

\begin{tabular}{|c|l|l|}
\hline No & \multicolumn{1}{|c|}{ Question indicator } & \multicolumn{1}{|c|}{ Opinion of Science Teachers } \\
\hline 1 & Definition of traditional games & $\begin{array}{l}\text { Respondent 1: "Traditional games are games that come from } \\
\text { the people without using high technology" } \\
\text { Respondent 2: "Traditional games are games that have been } \\
\text { passed down from generation to generation" } \\
\text { Respondent 3: "Traditional games are games that were } \\
\text { played by children in ancient times and most of the games } \\
\text { were played in groups" } \\
\text { Respondent 4: "Traditional games are games that arise from } \\
\text { an area and are played by local children" }\end{array}$ \\
\hline 2 & Traditional game types and sources & $\begin{array}{l}\text { Respondent 1: "The kinds of traditional games that I know } \\
\text { around my residence include gobak sodor, jamuran, } \\
\text { congklak, and unclang" }\end{array}$ \\
\hline
\end{tabular}




\begin{tabular}{|c|c|c|}
\hline No & Question indicator & Opinion of Science Teachers \\
\hline & & $\begin{array}{l}\text { Respondent 2: "Traditional games that I know in the area } \\
\text { include gangsing, eggrang, and various toys made of } \\
\text { bamboo" } \\
\text { Respondent 3: "The type of traditional games that I know are } \\
\text { congklak, hide and seek, dumbbells, and jumping rope. } \\
\text { However, I don't know the source" } \\
\text { Respondent 4: "The games in my area are gobak sodor, } \\
\text { eggrang, bekelan, dragon snake, jumping rope, engklek, } \\
\text { throwing gacuk / sandal, delikan / hide and seek, dakon / } \\
\text { congklak" }\end{array}$ \\
\hline 3 & $\begin{array}{l}\text { Integration of traditional games as } \\
\text { media science learning }\end{array}$ & $\begin{array}{l}\text { Respondent 1: "In my opinion, integrating traditional games in } \\
\text { science learning can provide direct learning experiences and } \\
\text { are easier for children to accept" } \\
\text { Respondent 2: "In my opinion, it is more creative and can be } \\
\text { trending forecasting in the future when integrating traditional } \\
\text { games in science learning" } \\
\text { Respondent 3: "In my opinion, it can introduce traditional } \\
\text { games to millennial children while learning science" } \\
\text { Respondent 4: "If it can be implemented, I agree It can } \\
\text { preserve traditional games. Besides, children can learn } \\
\text { science happily" }\end{array}$ \\
\hline 4 & $\begin{array}{l}\text { Strategies for integration and } \\
\text { traditional games that are relevant in } \\
\text { science learning }\end{array}$ & $\begin{array}{l}\text { Respondent 1: "I've never implemented it. In my opinion, the } \\
\text { application of integration of traditional games and science } \\
\text { learning adjusts to the conditions of students. For example, } \\
\text { jump height for measuring material and Tarik tambang for } \\
\text { force material" } \\
\text { Respondent 2: "I think through TGT. Because I have never } \\
\text { implemented it, I don't know which games are relevant for } \\
\text { learning science“" } \\
\text { Respondent 3: "I've never applied it, so I don't really know } \\
\text { which game to play. Possible strategies through groups and } \\
\text { demonstrations" } \\
\text { Respondent 4: "In my opinion, looking for traditional games } \\
\text { that can be applied when science learning takes place. I have } \\
\text { never applied it, so I don't know } \\
\text { which games are relevant for learning science" }\end{array}$ \\
\hline
\end{tabular}

The use of traditional games as media in science learning gets very positive views from each respondent. However, each teacher has different reasons for the importance of using traditional games in science learning. It can introduce and preserve traditional games for children to accept. The idea of engaging play in this education, aiming to enhance learning activities through interesting media that captures, retains student attention and interest in the subject, as well as offers an intuitive and collaborative environment [20], [21]. Games in learning scenarios engage learners into interactive, problem-solving situations that encourage critical thinking, communication, collaboration, and adaptability for functional knowledge acquisition [22]. Hence, integration of games in learning can engage and motivate students to actively process educational content and foster development processes within the child consciousness, also improve experience, self-efficacy, and students' satisfaction in similar learning environments [23]-[25]. 
As for the strategies that can be used, there are no fundamental differences between science teachers, namely integrating traditional games into relevant learning themes. This is because not all teachers have traditional games due to various inhibiting factors such as limited teacher lack of reading resources, lack of teacher understanding, inadequate facilities, and limited time. The analysis conducted by Kurniawan

Table 3. Kurniawan's analysis related to traditional games in science learning

\begin{tabular}{|c|l|l|}
\hline No & \multicolumn{1}{|c|}{ Material in Science Lessons } & \multicolumn{1}{c|}{ In the Games } \\
\hline 1 & Balance & Dhingklik, Oglak Aglik, Egrang, and Thuprok-thuprok \\
\hline 2 & Gravitation & $\begin{array}{l}\text { Dhingklik, Oglak Aglik, Egrang, Thuprok-thuprok, } \\
\text { Benthik, Bekel, Gasing, and Paseran }\end{array}$ \\
\hline 3 & $\begin{array}{l}\text { The living environment } \\
\text { around students }\end{array}$ & Ancang-ancang Alis \\
\hline 4 & Velocity & Benthik, Gasing, Paseran \\
\hline 5 & Rotation & Gasing \\
\hline 6 & Wind direction recognition & Layang-layang \\
\hline 7 & Power & Watu Gatheng, Paseran, Layang-layang, Marbles \\
\hline 8 & Target accuracy & Gatheng and Marbles \\
\hline
\end{tabular}

integrated traditional games in science learning so that games suitable for use by the teacher do not know it, only a respondent said that high jump can be used in measurement and Tarik tambang material for force material. Sulistyaningtyas \& Fauziah [26] argued that $45 \%$ of teachers still rarely apply

Therefore, integration of traditional games in science learning needs to be applied to introduce traditional games and science content contained in them, and improve the abilities of students, such as previous research studies [9], [17]-[19] it was found that use of traditional (Sasak, bentengan, congklak) as media in learning not only introduces traditional types of games but also improves students' abilities such as preservation of local culture, understanding concepts, learning outcomes, and learning motivation.

\section{CONCLUSION}

Based on the research results described above, several conclusions may be drawn. First, associated with the definition of traditional games, the majority of science teachers defined it as a folk game played by local children from ancient times, mostly in groups. However, the teachers not knowing the origin or source of traditional games. Second, the teachers have a positive view on the integration of traditional games in science learning to introducing and preserving traditional games while learning so on provide a direct learning experience and make it easier for children to accept. Third, traditional games which will be integrated as media in science learning will be seen from material elements and tools or
[27] states that 12 traditional games have a relationship between characteristics and content in science learning. The relationship between traditional games and science learning is seen from the material elements and the tools or materials used.

materials used so that have a relationship between characteristics and content in science learning. Based on these conclusions, the subsequent points may be recommended: 1) in-depth socialization is required regarding types and sources of traditional games to science teachers; 2) it's necessary to introduce traditional game-based learning models.

\section{AUTHORS' CONTRIBUTIONS}

All authors have contributed to the final draft. The contributions of each writer are as follows, DLH compiles the text and conceptualized the main idea, and $\mathbf{J}$ provides input and improvement.

\section{ACKNOWLEDGMENTS}

We thank the respondents for their participation in "fill out the survey and interview".

\section{REFERENCES}

[1] S. Suhono, Y.A. Sari, Retrofitting Javanese Traditional Games as Indonesia Culture Identity: Providing English Vocabulary, Jurnal Iqra' 2 
(2017)

213-226.

DOI:

https://doi.org/10.25217/ji.v2i1.123

[2] S. Tatminingsih, Sudarwo, Pengembangan Paket dan Strategi Pembelajaran IPA Melalui Permainan Tradisional untuk Siswa Kelas 3 SD di Daerah Rawan Bencana, Jurnal Pendidik dan Kebudayaan 18 (2012) 427-439. DOI: https://doi.org/10.24832/jpnk.v18i4.99

[3] E. Nugrahastuti, E. Puspitaningtyas, M. Puspitasri, M. Salimi, Nilai-nilai karakter pada permainan tradisional, in: Prosiding Seminar Nasional Inovasi Pendidikan, Inovasi Pembelajaran Berbasis Karakter dalam Menghadapi Masyarakat Ekonomi ASEAN, UNS, Solo, 2016, pp. 265-273.

[4] H. Marizona, Permainan Tradisional sebagai Kegiatan Ekstrakulikuler untuk Meningkatkan Kompetensi Social Siswa, An-Nafs: Kajian Penelitian Psikologi 2 (2017) 62-82. DOI: https://doi.org/10.33367/psi.v2i1.345

[5] G.M. Anggita, S.B. Mukarromah, M.A. Ali, Eksistensi Permainan Tradisional sebagai Warisan Budaya Bangsa, Journal of Sport Science and Education 3 (2018) 55-59. DOI: https://doi.org/10.26740/jossae.v3n2.p55-59

[6] N. Sahidun, Peningkatan Kecerdasan Interpersonal Anak Usia Dini Melalui Permainan Tradisional, Journal Early Childhood Care \& Education 1 (2018) 13-17. DOI: https://doi.org/10.26555/jecce.v1i1.4

[7] N.W.A. Majid, T. Ridwan, Development of The Traditional Digital Games for Strengthening Childhood's Verbal Skill, Jurnal Pendidikan Vokasi 9 (2019) 75-82. DOI: https://doi.org/10.21831/jpv.v9i1.22802

[8] A.G. Charles, M.R. Abdullah, R.M. Musa, The Effect of Traditional Games Intervention Programme in The Enhancement School-age Children's Motor Skills: A Preliminary Study, Movement Health \& Exercise 6 (2017) 157-169. DOI: https://doi.org/10.15282/mohe.v6i2.142

[9] Y. Sangaji, Permainan Tradisional Dalam Pembelajaran IPA untuk Meningkatkan Motivasi Belajar, Jurnal Pendidikan Guru Sekolah Dasar 7 (2018) 678-690.

[10] Y. Latif, Sosiokultur Sebagai Basis Pengembangan Ilmu Pengetahuan dan Teknologi, Sosioteknologi 13 (2014) 165-178.
DOI:

https://doi.org/10.5614/sostek.itbj.2014.13.3.1

[11] I.W. Suastra, Model Pembelajaran Sains Berbasis Budaya Local untuk Mengembangkan Kompetensi Dasar Sains dan Nilai Kearifan Lokal Di SMP, Jurnal Pendidikan dan Pembelajaran 43 (2010) 8-16.

[12] Ministry of Education and Culture of The Republic of Indonesia, Regulation of The Minister of Education And Culture of The Republic of Indonesia Number 35 of 2018 Concerning Amendments to The Regulation of The Minister Of Education And Culture Number 58 of 2014 Concerning The 2013 Curriculum for Junior High Schools, Ministry of Education and Culture of the Republic of Indonesia, Jakarta, 2018

[13] R.E. Simamora, S. Saragih, Hasratuddin, Improving Students' Mathematical Problem Solving Ability and Self-Efficacy through Guided Discovery Learning in Local Culture Context, International Electronic Journal of Mathematics Education 14 (2019) 61-72. DOI: https://doi.org/10.12973/iejme/3966

[14] I.N. Yenti, Pendekatan Kontekstual (Ctl) dan Implikasinya dalam Pembelajaran Matematika, Ta'dib, 12 (2012) 118-125. DOI: https://doi.org/10.31958/jt.v12i2.161

[15] N. Afni, Hartono, Contextual teaching and learning as a strategy to improve students mathematical literacy, Journal of Physics: Conference Series, vol. 1581, IOP Publishing, Bristol, 2020, pp. 1-8. DOI: https://doi.org/10.1088/17426596/1581/1/012043

[16] R.R. Aliyyah, D.R. Ayuntina, E.S.B Herawati, M. Suhardi, Ismail, Effort to Improve Learning Outcomes in Natural Science through Contextual Teaching And Learning Models, Indonesian Journal of Applied Research (IJAR), 1 (2020) 65-79. https://doi.org/10.30997/ijar.v1i2.50

[17] H.D. Ikawati, A. Purmadi, Z. Anwar, Zulfakar, Pengembangan Media Video Permainan Tradisional Suku Sasak untuk Pelestarian Budaya dan Sumber Belajar Muatan Lokal, Jurnal Teknologi Pendidikan 20 (2018) 234-248. DOI: https://doi.org/10.21009/jtp.v20i3.9536 
[18] D.S. Chichinnda, Raharjo, L. Rosdiana, Pengembangan Media Permainan Bentengan untuk Meningkatkan Pemahaman Konsep Siswa pada Materi Pemanasan Global, Jurnal Pendidikan Sains (2016) 1-6.

[19] U. Nurdiana, W. Widodo, Keefektifan Media Permainan Tradisional Congklak Untuk Meningkatkan Hasil Belajar Siswa, Jurnal Pendidikan Sains (2018) 161-164.

[20] C.I. Hitosugi, M. Schmidt, K. Hayashi, Digital Game-Based Learning (Dgbl) in The 12 Classroom: The Impact Of The Un's Off-TheShelf Videogame, Food Force, on Learner Affect And Vocabulary Retention, Calico Journal $31 \quad$ (2014) 19-39. DOI: https://doi.org/10.11139/cj.31.1.19-39

[21] J. Ter Vrugte, T. De Jong, S. Vandercruysse, P. Wouters, H. Van Oostendorp, J. Elen, How Competition and Heterogeneous Collaboration Interact in Prevocational Game-Based Mathematics Education, Computers and Education 89 (2015) 42-52. DOI: https://doi.org/10.1016/j.compedu.2015.08.010

[22] V. Trajkovik, T. Malinovski, T. VasilevaStojanovska, M. Vasileva, Traditional Games in Elementary School: Relationships of Student's Personality Traits Motivation and Experience With Learning Outcomes, PLoS ONE 13 (2018) $1-15$.

DOI: https://doi.org/10.1371/journal.pone.0202172

[23] S. Erhel, E. Jamet, Digital Game-based Learning: Impact of Instructions and Feedback on Motivation and Learning Effectiveness, Computers \& Education 67 (2013) 156-167. DOI:

https://doi.org/10.1016/j.compedu.2013.02.019

[24] C. Hung, J. Sun, P. Yu, The Benefits of A Challenge: Student Motivation and Flow Experience in Tablet-PC-Game-Based Learning, Interactive Learning Environments 23 (2015) 172-190.

DOI: https://doi.org/10.1080/10494820.2014.997248

[25] Y. Hsieh, Y. Lin, H. Hou, Exploring The Role of Flow Experience, Learning Performance and Potential Behaviour Clusters in Elementary Students' Game-based Learning, Interactive Learning Environments 24 (2016) 178-193. DOI: https://doi.org/10.1080/10494820.2013.834827
[26] R. E. Sulistyaningtyas, P.Y. Fauziah, The implementation of traditional games for early childhood education, in: $3^{\text {rd }}$ International Conference on Current Issues in Education (ICCIE 2018), Atlantis Press, Paris, France, 2019, pp. 431-435. DOI: https://doi.org/10.2991/iccie-18.2019.75

[27] M.R. Kurniawan, Analisis Permainan Tradisional dalam Implementasi Pendidikan Karakter di Sekolah Dasar, Metodik Didaktik 13 (2018) 99-105. DOI: https://doi.org/10.17509/md.v13i2.8553 